\title{
ПОРІВНЯЛЬНА ХАРАКТЕРИСТИКА СПОСОБІВ ЗАБОРУ ВЕНОЗНОЇ КРОВІ ДЛЯ ЛАБОРАТОРНОЇ ДІАГНОСТИКИ
}

\author{
В. А. Славопас \\ Приватний вищий навчальний заклад «Медичний коледж»
}

У статті висвітлено основні вимоги до преаналітичного етапу лабораторної діагностики, переваги та недоліки традищійних і сучасних способів забору венозної крові.

\section{THE COMPARATIVE CHARACTERISTICS OF THE METHODS OF COLLECTING OF THE VENOUS BLOOD FOR THE LABORATORY ANALYSIS}

\author{
V. A. Slavopas \\ Private Higher Educational Institution «Medical Colledge»
}

In the article the main demands for the preanalitical stage of the laboratory diagnostics, the strong and week points of traditional and modern methods of collecting of the venous blood are illuminated.

Вступ. Під час лікувально-діагностичного процесу для значної частини лабораторних аналізів проводиться забір венозної крові шляхом венепункції.

Це один з найбільш інформативних видів лабораторної діагностики. Забір венозної крові здійснюється для проведення різноманітних аналізів - біохімічних і генетичних досліджень, визначення гормонів, вірусів і ін.

Існує три способи взяття венозної крові:

- шприцом;

- голкою, коли кров вільно витікає в підставлену пробірку;

- вакуумними системами.

Правильність проведення діагностикивизначається якістю всіх етапів дослідження: преаналітичного, аналітичного, постаналітичного [1].

Основна частина. Преаналітичний етап - це всі процедури, що виконуються до початку проведення лабораторного дослідження: підготовка пацієнта, забір біоматеріалу, правильне його зберігання, транспортування і реєстрація.

Аналітичний етап - це безпосереднє проведення лабораторного тесту.

Постаналітичний етап - це оцінювання результатів дослідження і полягає у взаємодії працівників лабораторії та лікарів поліклініки чи стаціонару.
Дослідження показують, що на преаналітичному етапі здійснюється від 46 до 68 \% всіх лабораторних помилок, у результаті чого пацієнтам призначають неправильне лікування (6 \%) і непотрібні додаткові обстеження (19\%). Значна частина помилок зумовлена порушенням техніки взяття проб крові, неправильним вибором антикоагулянта, порушенням співвідношення кількості крові з реактивами, неправильними маніпуляціями з пробами [4].

Оптимальне проведення преаналітичної підготовки $\epsilon$ основною умовою точної та повної лабораторної діагностики.

Результати лабораторних досліджень можуть бути достовірними тільки у тому випадку, якщо будуть стандартизовані всі умови при взятті проб крові. Успішна венепункція - основна вимога адекватності зразків крові [2].

Не менш важливим є забезпечення вимог протиепідемічного режиму для зниження ризику виникнення гемоконтактних інфекцій при проведенні забору крові з вени.

Порушення при виконанні процедури взяття проб крові та маніпуляціях з ними можуть також слугувати причиною захворювання гемоконтактними інфекціями пацієнтів і медичного персоналу. Помилки при взятті проб венозної крові $\epsilon$ причиною інфікування медичного персоналу вірусними гепатитами В і С у 23-25 \% випадків [3]. 
Фактори, що впливають на якість лабораторного аналізу на етапі отримання зразка крові:

- час взяття крові;

- матеріал пробірок;

- дотримання співвідношення крові та антикоагулянта;

- черговість наповнення пробірок з різними добавками;

- тривалість накладання джгута;

- положення тіла пацієнта під час процедури;

- кваліфікація персоналу, який проводить венепункцію.

Для більшості досліджень проби крові потрібно брати 37 до 10 години ранку. Такий час забору гарантує необхідний період утримання від споживання їжі. Крім того, для більшості тестів референтні інтервали розроблені на основі досліджень зразків, отриманих саме в цей час доби. Також для деяких показників (залізо, ТТГ, паратгормон) відмічається суттєва зміна концентрації після 10 години. При повторному обстеженні пацієнта для більш обґрунтованого порівняння отриманих результатів, проби крові необхідно брати у той же час.

Прокол шкіри з видимими слідами етилового спирту на ній може призводити до гемолізу отриманої крові.

Однією $з$ важливих вимог при заборі крові $\epsilon$ дотримання певної послідовності наповнення пробірок з різними добавками. Так, для дослідження системи гемостаз необхідною умовою $є$ запобігання потраплянню в пробу тканинного тромбопластину з місця венепункції.

Черговість наповнення пробірок визначається переліком досліджень і видом добавок. Рекомендується дотримуватися такої послідовності:

- кров для мікробіологічного дослідження;

- цільна нативна кров (без антикоагулянта);

- цитратна кров;

- кров з гепарином;

- кров з інгібіторами гліколізу.

При всіх способах забору крові застосовується накладання джгута для створення венозного застою, який ще більше посилюється, коли пацієнту пропонують кілька разів стиснути та розтиснути кулак. Для деяких досліджень необхідно враховувати можливість підвищення рівня $\mathrm{K}^{+} \mathbf{i} \mathrm{Mg}^{++}$в результаті м'язової активності (стискання-розтискання кулака).

Всі дії по накладанню джгута необхідно виконувати швидко і послідовно. Тривалий спазм (більше 1 хви- лини) може спричинити зміну концентрації білка на 5-15\%, газів крові, електролітів, білірубіну, показників коагулограми. У випадках, коли пошук вени, яка підходить для пункції займає більше часу, необхідно зняти джгут і накласти його знову.

Останнім часом значна увага приділяеться положенню тіла пацієнта в момент взяття крові. Це пов'язано $з$ тим, що для деяких аналізів визначена суттєва різниця в концентраціях залежно від того, в положенні лежачи чи сидячи був пацієнт у момент забору біоматеріалу. Так, для прикладу, загальний білок і кальцій демонструють різницю концентрації близько $10 \%$, також виявлена залежність вмісту речовин у зразку крові відносно альдостерону, ліпопротеїну, С-реактивного білка. Чітких рекомендацій відносно положення тіла пацієнта в момент взяття крові не існує, однак бажано дотримуватися принципу відтворюваності умов взяття крові, що дозволяє коректно порівнювати результати аналізів у динаміці $[5,6]$.

Взяття крові голкою - це традиційний, відкритий спосіб із використанням голки та пробірки. Взяття крові проводиться стерильною голкою, під яку підкладають стерильну серветку. При цьому венозна кров природним шляхом витікає в підставлену пробірку. Перевагою цього способу $\in$ мінімальне пошкодження формених елементів крові за рахунок відсутності механічного пошкодження клітин під впливом поршня шприца та необхідності переливання крові в пробірку. Але при такому способі забору є висока ймовірність потрапляння біоматеріалу пацієнта на руки медичного персоналу.

Взяття крові за допомогою шприца становить певну небезпеку (ризик поранення голкою) для медичного персоналу. Крім цього, є можливість гемолізу крові, викликаного дворазовим проходженням крові через голку (забір крові в шприц і перенесення ії під тиском у пробірку). На момент переливання крові в пробірку вона також підпадає дії навколишнього середовища, що призводить до втрати стерильності та зниження якості зразка крові.

Для взяття проб крові найбільше надається перевага використанню вакуум-вмісній системі. Цей спосіб має ряд переваг, основною з яких є взяття крові безпосередньо з закриту пробірку, що запобігає будь-якому контакту з кров'ю пацієнта.

Переваги використання вакуум-вмісних систем:

- максимальна безпечність для медичних працівників і пацієнтів у зв'язку з відсутністю прямого контакту з кров'ю пацієнта на всіх етапах проведення забору; 
- стандартизація - взяття зразків крові по однотипній методиці, точне співвідношення об'єму крові і кількості реагенту, чітка ідентифікація за колірним кодом на етикетці;

- підвищення якості зразків сироватки та плазми крові;

- зручність і простота процедури (час взяття крові в одну пробірку становить всього лише 5-10 секунд, можливість швидкого використання двох і більше пробірок для різних аналізів без повторного введення голки);

- забір крові відбувається 3 мінімальними неприємними відчуттями;

- вакуумні системи для забору крові ідеально підходять для пацієнтів із тонкими і глибоко розташованими венами;

- скорочення кількості лабораторних помилок і повторних аналізів, які доводиться проводити через неякісний забір крові, ії підготовку, транспортування і зберігання;

- психологічний ефект для персоналу і пацієнтів (безпечність, зручність і швидкість процедури забору крові роблять ї̈ комфортною для пацієнта, сприятливо впливає на психологічний клімат у маніпуляційному кабінеті, підвищення працездатності персоналу,

\section{ЛITEPATYPA}

1. Клінічна біохімія : практикум / [Лаповець Л. Є., Луцик Б. Д., Порохнавець Л. Є. та ін.]. - 3-тє вид. - Львів, 2008. -230 c.

2. Біохімічні показники в нормі і при патології : навчальний довідник / [Д. П. Бойків, Т. І. Бондарчук, О. Л. Іванків та ін.] ; за ред. О. Я. Склярова. -К. : Медицина, 2007. - 320 c.

3. Горячковський О. М. Клінічна біохімія в лабораторній діагностиці : довідковий посібник / О. М. Горячковський. 3-тє вид., випр. і допов. - Одеса : Екологія, 2005. - 616 с. підвищення престижу лікувально-профілактичних закладів);

- можливість використання пробірки без відкривання кришки при центрифугуванні.

Щодо недоліків забору крові за допомогою вакуумвмісних систем, то за останні декілька років з'явились публікації, щодо інтерферуючого впливу матеріалу пробірок і речовин, які входять до складу розділюючих гелів, на визначення багатьох гормонів та онкомаркерів. Проте на даний час діючі міжнародні стандарти, які визначають вимоги і методи контролю виробництва приладів для забору крові, не вимагають дослідження впливу добавок на імунохімічний аналіз.

Висновки. Традиційний і найбільш поширений спосіб забору крові за допомогою шприца є основним джерелом лабораторних помилок, що призводить до низької якості аналізів. Крім цього, цей метод не може бути стандартизованим і не забезпечує безпеку персоналу і пацієнта під час забору крові. У той же час забір крові за допомогою вакуум-системи має ряд значних переваг і відповідає нормативним вимогам ведення преаналітичного етапу лабораторних досліджень.

За останні роки завдяки застосуванню сучасних технологій у клінічній практиці, суттєво зросла роль лабораторних досліджень у діагностиці та оцінці ефективності лікування різноманітних захворювань.

4. Сучасний стан здоров'я народу та напрямки його покращання в Україні : аналітично-статистичний посібник / за ред. В. М. Коваленка. - К., 2005. - 140 с.

5. Назаренко Г. И. Клиническая оценка результатов лабораторных исследований / Г. И. Назаренко, А. А. Кишкун. - М. : Медицина, 2006.

6. Proposed quality specifications for the imprecision and inaccuracy of analytical systems for clinical chemistry / C. G. Fraser, P. Hyltoft Petersen, C. Ricos, R. Haeckel // Eur. J. Clin. Chem. Clin. Biochem. - 1992. - Vol. 30. - P. 311-317. MedlineOrder article via InfotrieveWeb of Science. 